\title{
Pengembangan Kelembagaan dalam Rangka Peningkatan Manajemen Produk Ikan Teri di Desa Saramaake, Halmahera Timur, Maluku Utara
}

\section{(Institutional Development for Management Increase of Anchovy Product in Saramaake Village, East Halmahera, North Moluccas)}

\author{
Ujang Sehabudin ${ }^{1}$, Bahroin Tampubolon${ }^{1}$, Sulistiono ${ }^{2 *}$, Sudarmanto ${ }^{3}$, Arisyono ${ }^{3}$, Resna Handayani ${ }^{3}$ \\ ${ }^{1}$ Departemen Ekonomi Sumberdaya dan Lingkungan, Fakultas Ekonomi dan Manajemen, Institut Pertanian Bogor. \\ Kampus IPB Darmaga, Bogor 16680. \\ 2 Departemen Manajemen Sumberdaya Perairan, Fakultas Perikanan dan Ilmu Kelautan, Institut Pertanian Bogor. \\ Kampus IPB Darmaga, Bogor 16680. \\ ${ }^{3}$ Divisi Community Social Responsibility, PT ANTAM (Persero) Tbk, Jl. TB Simatupang, Jakarta 125303. \\ *Penulis Korespondensi: onosulistiono@gmail.com \\ Diterima Maret 2018/Disetujui Februari 2019
}

\begin{abstract}
ABSTRAK
Salah satu desa di wilayah Kabupaten Halmahera Timur yang dikenal dangan sentra hasil tangkapan ikan teri adalah Desa Saramaake. Kegiatan pemberdayaan masyarakat nelayan ini dilakukan selama 6 bulan sejak JuniDesember 2017, bertujuan untuk mengembangkan kelembagaan dalam rangka peningkatan pengelolaan produksi dan nilai tambah ikan teri. Metode kegiatan dilakukan melalui pelatihan dan pendampingan, baik oleh tim/tenaga ahli maupun tenaga pendamping lapangan. Lingkup kegiatan meliputi pengembangan kelembagaan, pelatihan, dan pendampingan. Pengembangan kelembangan diawali dengan pembentukan kelompok nelayan bagan dan kelompok pengolahan ikan, kemudian pembentukan Kelompuk Usaha Bersama (KUB), serta pembentukan koperasi. Data yang digunakan berupa data primer (hasil wawancara, pengamatan, dan pendampingan) dan data sekunder (profil wilayah dan produksi perikanan). Berdasarkan kegiatan yang dilakukan, kelembagaan yang sudah dibangun sejak 2016 ditingkatkan statusnya dari kelompok nelayan dan pengolah ikan, menjadi KUB, kemudian dikembangkan menjadi koperasi pada tahun 2017 dengan nama koperasi produsen Akesalaka Monge Bahari yang telah mendapatkan badan hukum No.006389/BH/M.KUKM.2/ $\mathrm{XI} / 2017$. Keberadaan koperasi ini mampu menerapkan proses kebersamaan dalam pengelolaan produksi ikan yang lebih baik dan pengembangan pasar yang lebih luas. Melalui pengembangan kelembagaan ini, para nelayan dan pengolah hasil laut dapat lebih mampu mengelola usahanya secara mandiri serta mampu meningkatkan bargaining position dalam pemasaran ikan teri dan produk olahan hasil laut lainnya.
\end{abstract}

Kata kunci: bargaining postition, koperasi, pemasaran, produksi

\begin{abstract}
One of the villages in East Halmahera Regency known as center of anchovy catch production area is Saramaake Village. The fishery community empowerment activities were carried out for 6 months from June to December 2017, aimed at developing institutions in order to improve production management and added value of anchovy. Methods used were training and mentoring conducted by experts and field mentors. The scope of activities includes institutional development, training, and mentoring. Institutional development was begun by lift-net fishermen and fish processing group establishment, developing business group (KUB-Indonesian) and cooperative. The data used was consisted of primary data (based on interview, observation, and mentoring) and secondary data (village profile and fish production). Based on activities carried out, the institution that has been built since 2016 has been upgraded from fishermen and fish processors groups, to business group (KUB), then developed into cooperatives in 2017. The Akesalaka Monge Bahari producer cooperative has obtained a legal entity No.006389/BH/M.KUKM.2/XI/2017. The cooperative was able to implement a better togetherness work to produce fish processing, and wider market development. Through this institutional development, fishermen and marine processors can be better to manage their business independently and be able to increase the bargaining position in the marketing of anchovy and other processed marine products.
\end{abstract}

Keywords: bargaining postition, coperative, marketing, production 


\section{PENDAHULUAN}

Negara Indonesia merupakan negara maritim yang terbesar di dunia. Negara ini memiliki pulau sebanyak 17.504 yang terbentang dari wilayah barat (Provinsi Aceh) sampai wilayah timur (Provinsi Papua). Di wilayah perairan ini, banyak tersimpan potensi sumber daya hayati yang dapat dimanfaatkan dan dikembangkan dalam rangka peningkatan pendapatan dan kesejahteraan masyarakat Indonesia. Namun demikian, potensi tersebut belum sepenuhnya dapat dimanfaatkan dengan baik, karena beberapa faktor baik keterampilan, teknologi maupun pemasaran. Salah satu sumber daya laut yang cukup besar dan memberikan sumber ekonomi bagi sebagian masyarakat Indonesia adalah ikan teri (Stolephorus spp). Ikan teri tersebar dan dipasarkan hampir di seluruh wilayah Indonesia. Ikan tersebut merupakan salah satu komoditas penting bagi masyarakat Indonesia dan bahkan merupakan salah satu komoditas ekspor penting yang dikirim ke berbagai negara.

Salah satu wilayah sentra produksi ikan teri adalah Kecamatan Wasile Selatan, Kabupaten Halmahera Timur, dengan sentra terbesar berada di Desa Saramaake. Berdasarkan data produksi ikan teri yang dicatat selama periode pelaksanaan kegiatan, produksi rata-rata ikan teri di Desa Saramaake tersebut mencapai 30 ton/ bulan. Produksi tersebut diperkirakan mencapai $70 \%$ dari produksi total ikan teri wilayah Kabupaten Halmahera Timur (Sulistiono et al. 2017). Dari total jumlah penduduk desa yang mencapai $200 \mathrm{KK}, 60 \%$ merupakan nelayan (penangkap ikan teri) dan sisanya terdiri atas petani/pekebun kelapa, PNS, dan pedagang (Desa Saramaake 2017). Berdasarkan hasil survei pasar, ikan teri dijual di Pasar Buli (Halmahera Timur) dan Ternate, bahkan telah tersebar di beberapa wilayah lain seperti Manado, Surabaya, dan Makasar (Sehabudin et al. 2017).

Beberapa kegiatan dan publikasi yang berkaitan dengan pemberdayaan masyarakat di Indonesia (nelayan dan pembudidaya ikan) telah dilakukan di beberapa tempat (Sipahelut 2010; Sulistiono et al. 2012; Nugroho 2015; Sulistiono et al. 2015; Yanti \& Permata 2016; Darmansah et al. 2016a; Darmansah et al. 2016b; Ma'arif et al. 2016; Insani et al. 2017; Utomo et al. 2018). Dari beberapa kegiatan tersebut, terdapat kemiripan pada model atau metode pemberdayaan yang dilakukan, yaitu pendekatan melalui pelatihan dan pendampingan, namun terdapat perbedaan dalam pengembangan kelembagaan di Desa Saramaake, yaitu sampai dengan terbentuknya koperasi.

Kegiatan pemberdayaan masyarakat di daerah Saramaake juga telah dilakukan dan telah dipublikasikan antara lain berkaitan dengan inisiasi pengembangan pasar (Sehabudin et al. 2017), peningkatan kualitas hasil dan diversifikasi produk (Budi et al. 2017), pengelolaan kegiatan pemberdayaan masyarakat (Sulistiono et al. 2018), pengembangan produk ikan teri dan sertifikasinya (Budi et al. 2018), edukasi pelestarian sumber daya dan lingkungan perikanan bagan (Sulistiono et al. 2018). Sedangkan publikasi yang berkaitan dengan kelembagaan, kelompok, dan koperasi dalam rangka peningkatan pengelolaan produksi hasil laut secara khusus belum disampaikan. Paper ini bertujuan untuk mengetahui perkembangan dan peran kelembagaan/koperasi dalam rangka peningkatan manajemen produksi ikan teri dan produk laut lainnya di Desa Saramaake, Kabupaten Halmahera Timur, Maluku Utara.

\section{METODE PELAKSANAAN KEGIATAN}

\section{Waktu dan Tempat}

Kegiatan pemberdayaan masyarakat melalui pengembangan kelembagaan dalam rangka peningkatan manajemen produksi ikan teri dan produk olahan likan aut dilakukan selama 6 bulan, sejak Juni-Desember 2017 di Desa Saramaake, Kecamatan Wasile Selatan, Kabupaten Halmahera Timur, Maluku Utara (Gambar 1).

\section{Bahan dan Alat}

Bahan yang diperlukan dalam kegiatan ini berupa modul pelatihan perkoperasian (UU Koperasi, akta pendirian koperasi, dan angaran dasar koperasi) dan software aplikasi laporan keuangan koperasi. Sementara itu peralatan yang digunakan antara lain papan tulis, LCD, layar, laptop, dan peralatan tulis.

\section{Metode Pelaksanaan dan Analisis Data}

Metode palaksanaan kegiatan secara umum terdiri atas pelatihan dan pendampingan, mulai dari tahap persiapan pembentukan koperasi dari KUB, proses pembentukan akta pendirian koperasi melalui notaris, penyiapan dan penyusunan anggaran dasar koperasi, sampai dengan diterbitkannya badan hukum koperasi. Rapat 


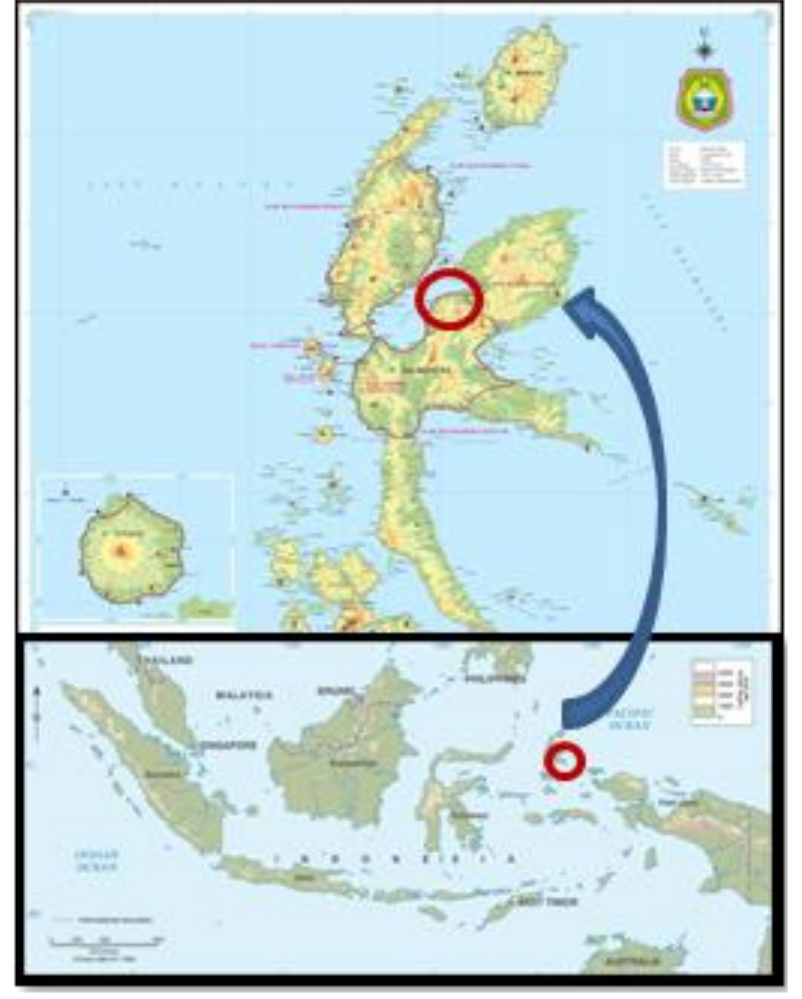

Gambar 1 Lokasi kegiatan pengembangan kelembagaan di Desa Saramaake, Halmahera Timur, Provinsi Maluku Utara.

persiapan pembentukan koperasi diikuti oleh anggota KUB, yang beranggotakan kelompok nelayan dan kelompok pengolahan hasil, dihadiri oleh pejabat Dinas Perindagkop Kabupaten Halmahera Timur sekaligus menyampaikan materi dan sosialisasi perkoperasian. Pada rapat persiapan disepakati nama koperasi, yaitu koperasi Akesalaka Monge Bahari, dengan jenis koperasi produsen. Rapat juga menyusun kepengurusan koperasi, terdiri dari ketua, sekretaris, dan bendahara, serta pembentukan badan pengawas yang terdiri dari ketua dan anggota. Selanjutnya dokumen rapat persiapan (daftar hadir, pengurus, dan badan pengawas) dan neraca awal koperasi disampaikan ke notaris sebagai persyaratan akta pendirian koperasi kepada notaris. Notaris yang memproses akta pendirian dan badan hukum koperasi merupakan notaris yang memiliki kewenangan untuk itu, berdomisili di Kota Ternate. Proses pendaftaran akte pendirian koperasi kepada notaris dilakukan oleh ketua koperasi. Setelah didaftarkan, selanjutnya notaris memproses badan hukum koperasi ke Kementerian Koperasi dan UKM secara online, sampai terbitnya badan hukum koperasi.

Dalam rangka pengelolaan koperasi, maka dilakukan pelatihan perkoperasian meliputi pelatihan manajemen/tata kelola koperasi, pelatihan administrasi, dan pencatatan laporan keuangan koperasi, pendampingan penyusunan Anggaran Dasar dan Angagran Rumah Tangga (AD-ART) koperasi, serta pendampingan pemasaran hasil produksi (teri, olahan teri, dan produk laut lainnya).

Monitoring dan evaluasi (monev) dilakukan oleh tim secara periodik dalam rangka efektivitas pelaksanaan program, sesuai dengan tahapan dan proses kegiatan. Monev dilakukan untuk memastikan agar seluruh rangkaian proses dan lingkup kegiatan pengembangan kelembagaan koperasi dapat berjalan sesuai harapan. Monev dilakukan terhadap sasaran penerima program khususnya anggota dan pengurus koperasi. Analisis data menggunkan analisis deskriptif dengan data kuantitatif maupun kualitatif yang bersumber dari hasil pengamatan lapangan, pelatihan, dan pendampingan yang bersumber dari pengurus dan anggota koperasi, pemerintah daerah, maupun hasil pengamatan lapangan dan survei pemasaran produk olahan ikan teri dan ikan laut lainnya di beberapa lokasi (Buli, Ternate, dan Manado).

\section{HASIL DAN PEMBAHASAN}

\section{Upaya Pembentukan Koperasi}

Sebagai tindak lanjut dari pengembangan KUB Monge mulai Agustus 2017 disiapkan proses pembentukan koperasi, yang kemudian diberi nama Koperasi Akesalaka Monge Bahari. Saat ini koperasi tersebut telah mendapatkan badan hukum No.006389/BH/M.KUKM.2/XI/2017. Koperasi ini merupakan koperasi produsen pertama yang berdiri di Desa Saramaake bahkan di Kabupaten Halmahera Timur yang bergerak pada kegiatan produksi (penangkapan ikan laut dan produksi olahan ikan laut khususnya teri). Proses pembentukan koperasi, dimulai dengan kegiatan rapat persiapan pembentukan koperasi yang dihadiri oleh anggota KUB Monge, kemudian sosialisasi pembentukan koperasi yang dilakukan oleh Dinas Koperasi, UMKM, Perdagangan, dan Perindustrian Kabuapten Halmahera Timur bertempat di kantor Kepala Desa Saramake, pembentukan pengurus koperasi, pendaftaran akte pendirian koperasi kepada notaris di Ternate, kemudian proses pendaftaran koperasi ke Kementerian Koperasi dan UKM (secara online oleh notaris), pemantauan proses pendaftaran sampai dengan terbitnya badan hukum koperasi. 
Kegiatan koperasi masih terbatas pada produksi dan pemasaran ikan teri mentah, olahan ikan teri, dan olahan hasil laut lainnya (cumi dan makecina). Bahan baku olahan tersebut berasal dari hasil tangkapan para nelayan setempat yang diolah dan diproduksi menjadikan berbagai produk olahan yang memberikan nilai tambah ekonomi, seperti teri crispy, sambal teri, makecina, dan produk olahan lainnya. Produk olahan tersebut telah dipasarkan ke Buli, Maba, hingga Ternate. Produk tersebut dijadikan oleholeh khas Halmahera Timur. Kegiatan produksi olahan tersebut dilakukan oleh kelompok pengolah ikan anggota koperasi yang umumnya ibu-ibu.

Proses pembentukan koperasi, mulai rapat persiapan sampai dengan terbitnya badan hukum koperasi memerlukan waktu yang cukup lama sekitar 5 bulan, dengan kegiatan sebagai berikut:

- Melengkapi dokumen persyaratan administrasi pendirian koperasi, yang harus dilengkapi seperti daftar hadir peserta rapat persiapan pembentukan koperasi, draf ADART, susunan pengurus dan pengawas koperasi dilengkapi dengan fotokopi KTP, neraca koperasi awal, nama, dan alamat sekretariat koperasi

- Melakukan komunikasi yang lebih intensif antara pengurus koperasi dengan notaris terkait dengan proses pengurusan dan pendirian koperasi, hal ini karena domisili notaris di Kota Ternate yang jaraknya cukup jauh dari domisili koperasi (Desa Saramaake) sehingga memerlukan waktu dan biaya yang cukup besar.

- Memastikan agar proses entri data persyaratan kelengkapan pendirian koperasi secara online yang dilakukan notaris ke web Kementerian Koperasi dan UKM berjalan dengan baik, melalui pengecekan secara reguler oleh pendamping secara langsung ke notaris, selain komunikasi melalui telepon.

\section{Peningkatan Kapasitas Sumber Daya Manusia Koperasi}

\section{- Pelatihan manajemen koperasi}

Pengetahuan, pemahaman, dan keterampilan pengurus, pengawas, dan anggota mengenai perkoperasian masih terbatas. Peningkatan kualitas SDM pengelola koperasi dilakukan dengan pelatihan dan pendampingan berupa 1) Manajemen/tata kelola koperasi; 2) Penyusunan dan penyempurnaan AD-ART koperasi; dan 3)
Administrasi dan laporan keuangan koperasi. Pelatihan dan pendampingan ini bertempat di sekretariat Koperasi Akesalaka Monge Bahari, yang dihadiri oleh pengurus, pengawas, dan anggota koperasi (Gambar 2).

Pelatihan manajemen koperasi bertujuan untuk memberikan pemahaman dan keterampilan kepada pengurus dan anggota koperasi mengenai tata kelola menjalankan koperasi (manajemen koperasi) berdasarkan dengan UU Koperasi, AD-ART koperasi. Pelatihan manajemen koperasi dihadiri 14 orang terdiri dari pengurus, pengawas, dan anggota yang dilakukan di sekretariat koperasi. Pelatihan dimulai dengan pembahasan ART koperasi yang drafnya sudah disiapkan sebelumnya. Beberapa hal dibahas dan disepakati dalam ART antara lain persyaratan anggota, rapat anggota, rapat anggota tahunan (RAT), pemilihan pengurus atau pengawas, dan jangka waktu pembagian sisa hasil usaha serta sanksi yang diterapkan apabila terjadi pelanggaran. Hal-hal yang disepakati dalam penyusunan ART adalah pertama, persyaratan untuk menjadi anggota adalah Warga Negara Indonesia (WNI) minimal berusia 18 tahun atau sudah/pernah menikah dan membayar simpanan pokok sebesar Rp 1.000.000 yang dapat dicicil selama satu tahun, dan simpanan wajib sebesar Rp 20.000/bulan. Simpanan pokok dan wajib dapat dibayarkan dalam bentuk uang atau ikan teri.

Kedua, rapat anggota diumumkan selambatlambatnya tujuh hari sebelum rapat kepada anggota dan rapat dipimpin oleh pengurus atau pengawas. Khusus untuk Rapat Anggota Tahunan (RAT), diselenggarakan setiap tahun dan paling lambat tiga bulan setelah tutup buku berakhir. Ketiga, kepengurusan, jangka waktu masa jabatan pengurus dan pengawas adalah selama tiga tahun dan dapat dipilih kembali untuk masa

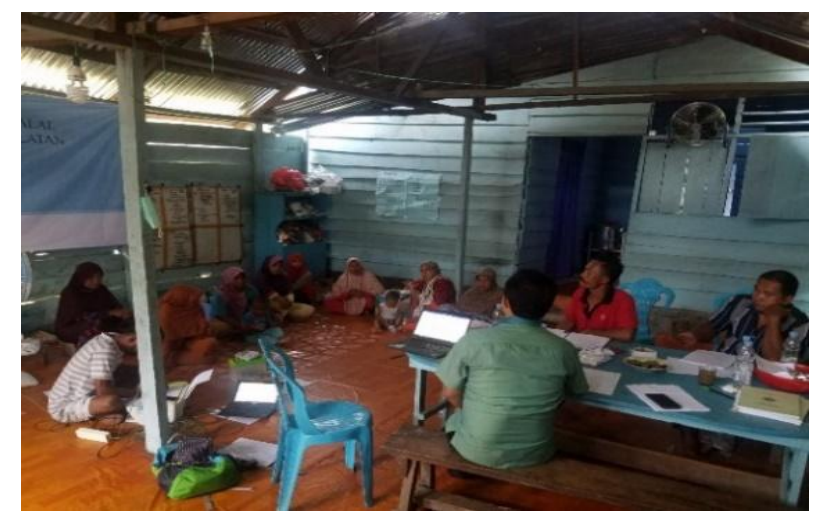

Gambar 2 Pelatihan manajemen Koperasi Akesalaka Monge Bahari di Desa Saramaake. 
jabatan berikutnya. Pemilihan pengurus koperasi dilakukan oleh anggota melalui RAT. Keempat, peruntukan sisa hasil usaha (SHU): 40\% digunakan untuk modal atau cadangan usaha, $30 \%$ dibagikan kepada anggota berdasarkan perimbangan simpanan, $15 \%$ untuk pengurus, $10 \%$ untuk pengawas, dan $5 \%$ untuk dana sosial serta pendidikan. Kelima, sanksi yang dapat diberikan apabila terjadi pelanggaran adalah berupa peringatan hingga diberhentikan atau dikeluarkan dari keanggotaan koperasi. ART yang disepakati ini menjadi pedoman bagi pengurus, pengawas dan anggota dalam menjalankan koperasi.

Setelah pembahasan ART, selanjutnya dilakukan penjelasan struktur organisasi Koperasi Akesalaka Monge Bahari, tugas dan peran pengurus serta pengawas, hak dan kewajiban anggota, permodalan koperasi, rapat anggota, rencana kerja dan usaha, serta partisipasi anggota. Khusus untuk masalah partisipasi anggota, masih terdapat persepsi yang menganggap: 1) Tujuan koperasi tidak selaras dengan keinginan beberapa anggota dan 2) Koperasi berpotensi menjadi pesaing kegiatan usaha anggota. Struktur organisasi Koperasi Akesalaka Monge Bahari disusun dalam rangka fektivitas peran dan fungsi koperasi (Gambar 3). Struktur tersebut menampilkan hirarki koperasi, di mana kedudukan tertinggi berada pada Rapat Anggota Tahunan (RAT).

Kegiatan pelatihan selanjutnya adalah pelatihan administrasi dan pelaporan keuangan koperasi sesuai dengan format yang berlaku

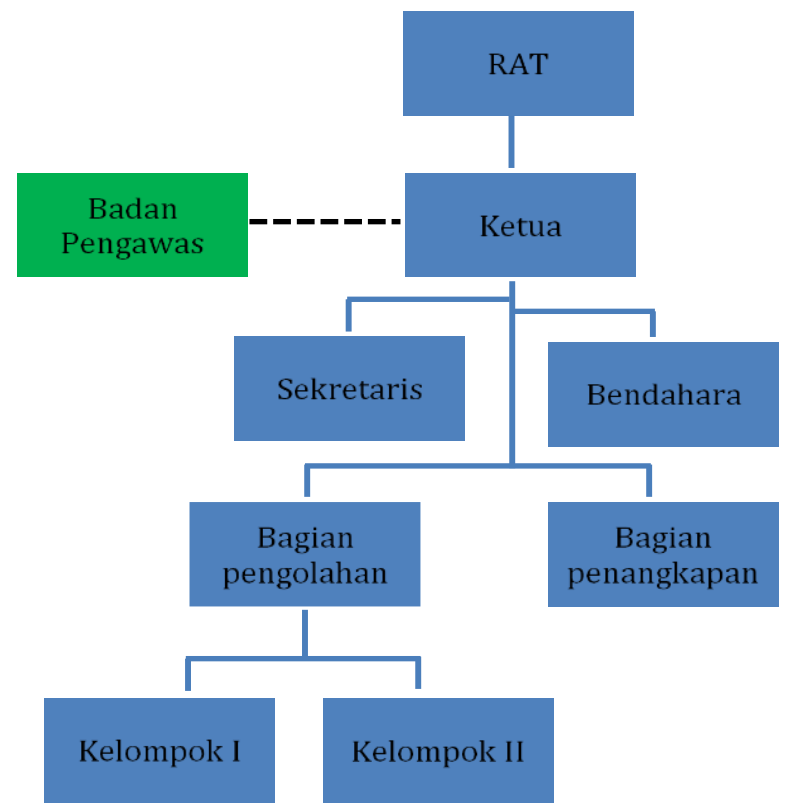

Gambar 3 Struktur organisasi Koperasi Akesalaka Monge Bahari. dengan menggunakan software keuangan khusus yang mengacu kepada kaidah-kaidah sistem akuntansi koperasi. Pelatihan ini khusus diperuntukan bagi bendahara koperasi dan calon karyawan koperasi yang ditugaskan sebagai pelaksana pengelolaan administrasi khususnya pencataan transaksi dan pelaporan koperasi.

\section{- Pelatihan administrasi dan laporan keuangan koperasi}

Pelatihan administrasi dan laporan keuangan koperasi pada awalnya diperuntukan pengurus terutama bendahara koperasi, namun ternyata minat dari anggota untuk ikut dalam pelatihan cukup tinggi sehingga dalam pelatihan ini terdapat enam orang peserta. Keenam peserta tersebut adalah pengurus sebanyak tiga orang, pengawas satu orang, dan anggota dua orang. Pelatihan dilakukan di sekretariat Koperasi Akesalaka Monge Bahari. Pelatihan diawali dengan penjelasan mengenai pentingnya pencatatan aktivitas/transaksi keuangan yang dilakukan koperasi. Pada pelatihan ini diberikan contoh penggunaan form bukti transaksi yang umumnya dilakukan koperasi, seperti bukti penerimaan kas dan pembayaran bahan baku atau jasa.

Setelah diberikan materi pencatatan/ administrasi transaksi yang dilengkapi dengan contoh bukti transaksi seperti form dan kuitansi, kemudian dilanjutkan dengan menginput catatan transaksi keuangan ke dalam format yang disiapkan mulai dari jurnal, buku besar, laporan laba rugi, dan neraca koperasi dengan menggunakan software excel. Format tersebut dibuat dan disiapkan agar dapat memudahkan pengurus khususnya bendahara dalam melaporkan catatan keuangan koperasi. Pendampingan dilakukan oleh pendamping lapangan yang sebelumnya telah diberikan pelatihan, dalam upaya efektivitas pelatihan.

\section{Pemasaran Produk}

Upaya peningkatan pemasaran produk hasil olahan ikan teri dan olahan ikan laut lainnya dilakukan dengan berbagai kerja sama penjualan dengan toko atau warung yang berada di sepanjang jalan lintas Halmahera Timur. Saat ini, tercatat dua warung makan yang telah menjalin kerja sama titip jual untuk produk olahan ikan teri, yaitu warung makan Wisma Kita dan Lina di Subaim, Kecamatan Wasile Selatan. Sebelumnya kerja sama pemasaran telah dijalin dengan Buli Mart di Buli dan Koperasi PT Antam di Ternate. 
Pengamatan yang dilakukan dihasilkan beberapa informasi menarik sebagai bahan masukan dalam pengembangan produk olahan ikan. Target pasar awalnya memang diperuntukan bagi para wisatawan atau pekerja proyek termasuk pegawai PT Antam sebagai oleh-oleh khas Saramaake. Kendala yang ada antara lain harga yang dipandang terlalu mahal seperti yang dikeluhkan oleh para calon pembeli lokal. Hal ini dapat dipahami mengingat ikan teri merupakan konsumsi sehari-hari yang biasanya harganya lebih murah dan tidak dikemas khusus, sementara teri olahan dikemas secara khusus sehingga harganya lebih mahal. Produk ikan teri olahan yang dijual oleh kedua warung tersebut telah dipajang pada tempat yang cukup terlihat oleh calon konsumen. Display produk olahan ikan teri berupa sambal di salah satu warung disajikan Gambar 4.

\section{Upaya Pengembangan Koperasi}

Pengembangan dan pembinaan koperasi selanjutnya dilakukan koordinasi dengan Dinas Koperasi dan UKM Provinsi Maluku Utara, serta Dinas Perikanan dan Kelautan Provinsi Maluku Utara. Tujuan dari kegiatan ini adalah untuk penyebarluasan informasi kegiatan Koperasi Akesalaka Monge Bahari sekaligus inisiasi peluang kerja sama atau integrasi program pemerintah daerah yang dapat dikembangkan dalam rangka pengembangan koperasi di masa mendatang.

Tim IPB menyampaikan perkembangan kegiatan pemberdayaan masyarakat di Desa Saramaake, Halmahera Timur termasuk kemungkinan peluang kerja sama lebih lanjut dengan Dinas Perikanan dan Kelautan (DKP) Provinsi Maluku Utara dalam pengembangan program perikanan di Halmahera Timur khususnya di Desa Saramaake, melalui integrasi program dinas. Pihak Dinas Perikanan dan Keluatan Provinsi Maluku memberiakan apresiasi kepada IPB yang telah membina masyarakat nelayan di Saramaake selama 2 tahun ini. Pihak Dinas berupaya dapat mengintegrasikan program dinas dengan program pembinaan yang telah dilakukan IPB, bahkan ke depan program pembinaan IPB dapat menjadi contoh bagi program yang sejenis yang akan dikembangkan oleh Dinas Perikanan dan Keluatan Provinsi Maluku.

Penyampaian dan diskusi program pemberdayaan masyarakat di Desa Saramaake juga dilakukan kepada Dinas Koperasi Usaha Mikro, Kecil, dan Menengah Provinsi Maluku Utara melalui kepala dinas dan dihadiri staf dinas. Diskusi tersebut juga dihadiri Pengurus Koperasi Pemuda Tani Indonesia Sofifi, dengan hasil diskusi sebagai berikut:

- Kegiatan pendampingan pengembangan nelayan yang dilakukan IPB di Desa Saramaake dapat menjadi percontohan untuk menggiatkan aktivitas-aktivtas serupa di Provinsi Maluku Utara.

- Pemerintah Provinsi Maluku Utara mengharapkan agar IPB dapat mendampingi Koperasi Produsen Pemuda Tani Indonesia, dalam pengembangan tanaman pangan dan holtikultura, khususnya dalam peningkatan kapasitas SDP pengelola dalam aspek manajemen koperasi dan teknis budidaya tanaman pangan khususnya jagung. Diharapkan kerja sama dapat segera ditindaklanjuti dimulai dengan penandatangan MoU antara Gubernur Maluku Utara dengan IPB.

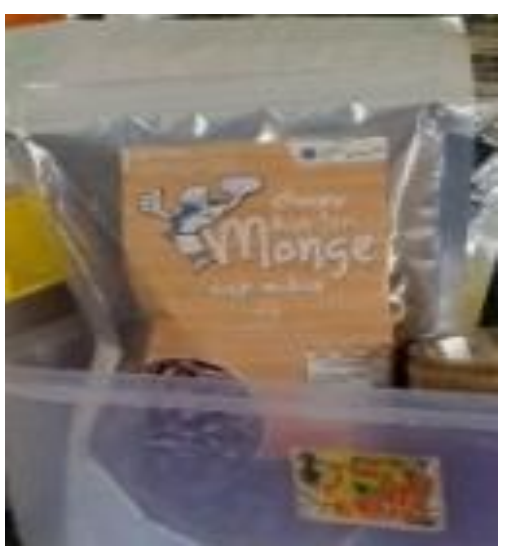

a

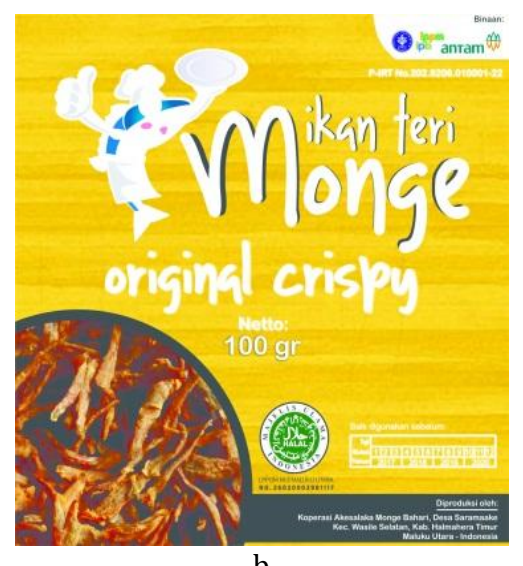

b

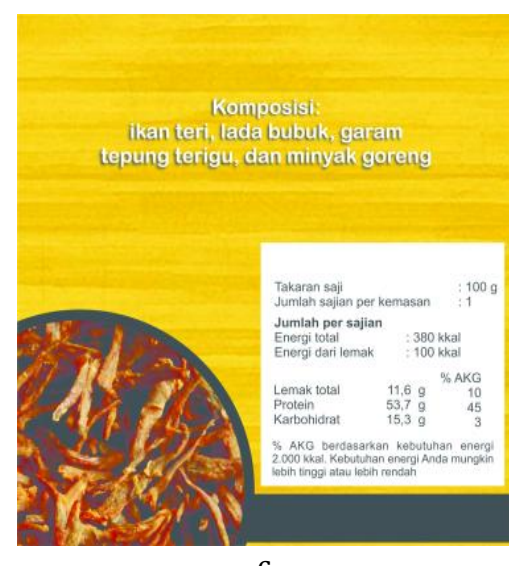

C

Gambar 4 Produk dan kemasan olahan ikan teri di warung Wisma Kita, Kecamatan Subaim (a), Kemasan produk olahan ikan teri tampak depan dengan logo MUI dan tampak belakang dengan komposisi yang terkandung dalam kemasan (b dan c). 
- Kepala Dinas Koperasi Usaha Mikro, Kecil, dan Menengah Provinsi Maluku Utara juga menyampaikan keinginannya untuk dapat berkunjung melihat kegiatan pengembangan Koperasi Produsen Akesalaka Monge Bahari di Desa Saramaake.

- Tim IPB menyampaikan bahwa semangat berkoperasi yang mulai tumbuh di Provinsi Maluku Utara perlu dikawal dan dikembangkan melalui fasilitasi pemerintah daerah bekerja sama dengan perguruan tinggi dan dunia usaha sesuai dengan kompetensi dan kewenangan masing-masing pihak.

- Tim IPB menyarankan agar dibuat MoU antara Pemerintah Provinsi Maluku Utara dengan IPB sebagai payung hukum untuk pengembangan kerja sama selanjutnya. Implementasi kerja sama dilakukan oleh Dinas terkait seperti DKP, Dinas Koperasi, dan UKM dengan LPPM IPB sebagai pihak yang mengkoordinasikan kegiatan penelitian dan pengabdian kepada masyarakat.

\section{Pembahasan}

Proses pengembangan kelembagaan Koperasi Aesalaka Monge Bahari di Desa Saramaake, diawali dengan pembentukan kelompok produksi/ penangkapan ikan dan kelompok pengolahan produk ikan, kemudian pembentukan Kelompok Usaha Bersama (KUB), sama dengan proses pembentukan koperasi. Pembentukan kelompok produksi/penangkapan ikan yang beranggotakan nelayan bagan dan karyawan bagan bertujuan untuk meningkatkan kualitas dan produktivitas hasil tangkapan, meliputi penanganan hasil tangkapan di bagan, proses penjemuran, dan pengemasan. Inovasi teknologi penanganan hasil tangkapan ikan di bagan antara lain penggunaan keranjang untuk menampung ikan agar darah ikan, kotoran, dan air laut terpisah dengan ikan tangkapan sehingga ikan lebih higienis; untuk proses penjemuran dilakukan penambahahan jemuran dengan tambahan plastik penutup untuk menutupi ikan yang dijemur ketika terjadi hujan; serta inovasi alat pengepres untuk pengememasan ikan teri kering ke dalam karung.

Pembentukan kelompok pengolahan produk ikan yang beranggotaka istri-istri nelayan bagan pada dasarnya bertujuan meningkatkan diversifikasi produk dan nilai tambah ikan; selama ini produk yang dihasilkan hanya ikan kering khususnya teri. Pembentukan kelompok pengolahan produk ikan juga bertujuan memanfaatkan waktu luang istri-istri nelayan untuk menambah penghasilan keluarga. Pendampingan yang dilakukan mulai dari proses produksi, pengemasan, PIRT, dan proses sertifikasi halal.

Sebagai tindak lanjut pembentukan kelompok, selanjutnya dibentuk Kelompok Usaha Bersama (KUB) yang beranggotakan kelompok produksi/ penangkapan ikan dan kelompok pengolahan produk ikan dengan tujuan menciptakan sinergitas antar kelompok. Melalui KUB, komunikasi dan koordinasi program dan kegiatan pemberdayaan menjadi lebih mudah dan lebih efektif, baik internal maupun dengan pihak eksternal KUB terutama dalam pemasaran produk olahan ikan. Proses pemasaran produk olahan ikan didampingi oleh tenaga pendamping lapangan.

Peningkatan peran dan fungsi kelembagaan dilakukan dengan dibentuknya koperasi untuk mengatasi keterbatasan KUB terutama dalam proses transaksi yang bersifat legal, yang selama ini tidak bisa dilakukan oleh KUB. Proses pembentukan koperasi diawali dengan rapat persiapan yang dihadiri oleh seluruh anggota KUB dan difasilitasi oleh Tenaga Ahli IPB serta Dinas Perindustrian, Perdagangan, dan Koperasi UMKM Kab Halmahera Timur. Pada rapat pembentukan dilakukan sosialisasi perkoperasian (latar belakang, tujuan, prinsip, manfaat, dan persyaratan pembentukan koperasi). Berita acara dan daftar hadir peserta rapat persiapan menjadi salah satu persyaratan pembentukan. Pembentukan pengurus dan badan pengawas koperasi; kesepakatan besarnya simpanan pokok dan wajib; serta penyusunan neraca awal koperasi sebagai persayaratan pendirian koperasi juga dilakukan dalam rapat persiapan. Seluruh dokumen tersebut, kemudian dilengkapi dengan surat rekomendasi pembentukan koperasi dari Dinas Perindustrian, Perdagangan, dan Koperasi UMKM Kabupaten Halmahera Timur.

Setelah seluruh dokumen persyaratan pembentukan koperasi lengkap, kemudian dokumen tersebut dibawa ke notaris di Ternate untuk dibuat akta pendirian koperasi, kemudian didaftarkan ke Kementerian Koperasi dan UKM RI untuk mendapatkan badan hukum koperasi. Proses pendaftaran sampai dengan keluarnya badan hukum koperasi memerlukan waktu yang cukup lama, sekitar 5 bulan dari target 3 bulan. Hal ini selain karena proses pendaftaran sampai dengan penetapan badan hukum dilakukan secara terpusat, berbeda dengan aturan sebelumnya yang penetapan badan hukum dilakukan oleh kepala dinas yang menangani koperasi di kabupaten/kota. Saat ini penetapan badan 
hukum dilakukan oleh Kementerian Koperasi dan UKM RI. Kendala lainnya adalah proses pendaftaran koperasi yang dilakukan secara online seringkali terhambat oleh keterbatasan jaringan/teknologi informasi yang cukup lambat dari daerah ke pusat Jakarta). Berbeda dengan pengalaman proses pembentukan Koperasi Kampung Sutera Garut (Sehabudin et al. 2016), waktu yang diperlukan relatif cepat sekitar 3 bulan dari mulai rapat persiapan, akta notaris, sampai dengan penatapan badan hukum. Hal ini karena penatapan badan hukum koperasi cukup dari Kepala Dinas Koperasi dan UKM Kabupaten Garut, walaupun prosesnya didaftarkan ke Kementerian Koperasi dan UKM. Kendala lainnya dalam pembentukan koperasi adalah cukup mahalnya biaya akta pembentukan koperasi di notaris, seperti pembentukan Koperasi Aesalaka Monge Bahari yang mencapai Rp 6 juta di Ternate, walaupun biaya notaris pembentukan KKSG di Garut lebih rendah, mencapai Rp 3 juta. Hal ini cukup berat jika biaya tersebut ditanggung oleh kelompok masyarakat yang akan mendirikan koperasi.

Peningkatan pengetahuan perkoperasian dan keterampilan manajemen koperasi, dilakukan dengan pelatihan dan pendampingan koperasi, antara lain dalam hal pengetahuan perkoperasian, manajemen/tata kelola/administrasi koperasi termasuk administrasi, dan laporan keuangan koperasi. Secara umum adanya pelatihan dan pendampingan mampu meningkatkan pengetahuan dan pemahaman SDM koperasi mengenai manajemen koperasi khususnya pengetahuan mengenai hak anggota, perangkat organisasi, kekuasaan tertinggi, dan adminstrasi/ pencataan transaksi (Gambar 5). Manfaat pelatihan terhadap peningkatan pengetahuan pengurus koperasi dalam administrasi koperasi hampir sama dengan yang terjadi pada proses kasus pelatihan perkoperasian pada KKSG, walaupun kategorinya tergolong cukup (Sehabudin et al. 2017).

Program pengembangan kelembagaan/koperasi dalam rangka peningkatan manajemen produksi hasil laut di Desa Saramaake dapat berjalan dengan baik karena dukungan berbagai pihak, baik PT Antam sebagai perusahaan yang mempunyai tanggung jawab sosial terhadap masyarakat, IPB sebagai pendamping dan pelaksana program, pemerintah daerah (kabupaten, kecamatan, dan desa), serta masyarakat/kelompok sasaran (nelayan). Partisipasi merupakan kunci keberhasilan program seperti diungkapkan oleh Nasdian (2014) yang menyatakan bahwa partisipasi merupakan proses aktif, inisiatif warga komunitas, dibimbing oleh cara berpikir mereka sendiri dengan menggunakan sarana dan proses (lembaga dan mekanisme) di mana mereka dapat menegaskan kontrol secara efektif.

Lembaga koperasi oleh banyak kalangan, diyakini sangat sesuai dengan budaya dan tata kehidupan bangsa Indonesia, di dalamnya

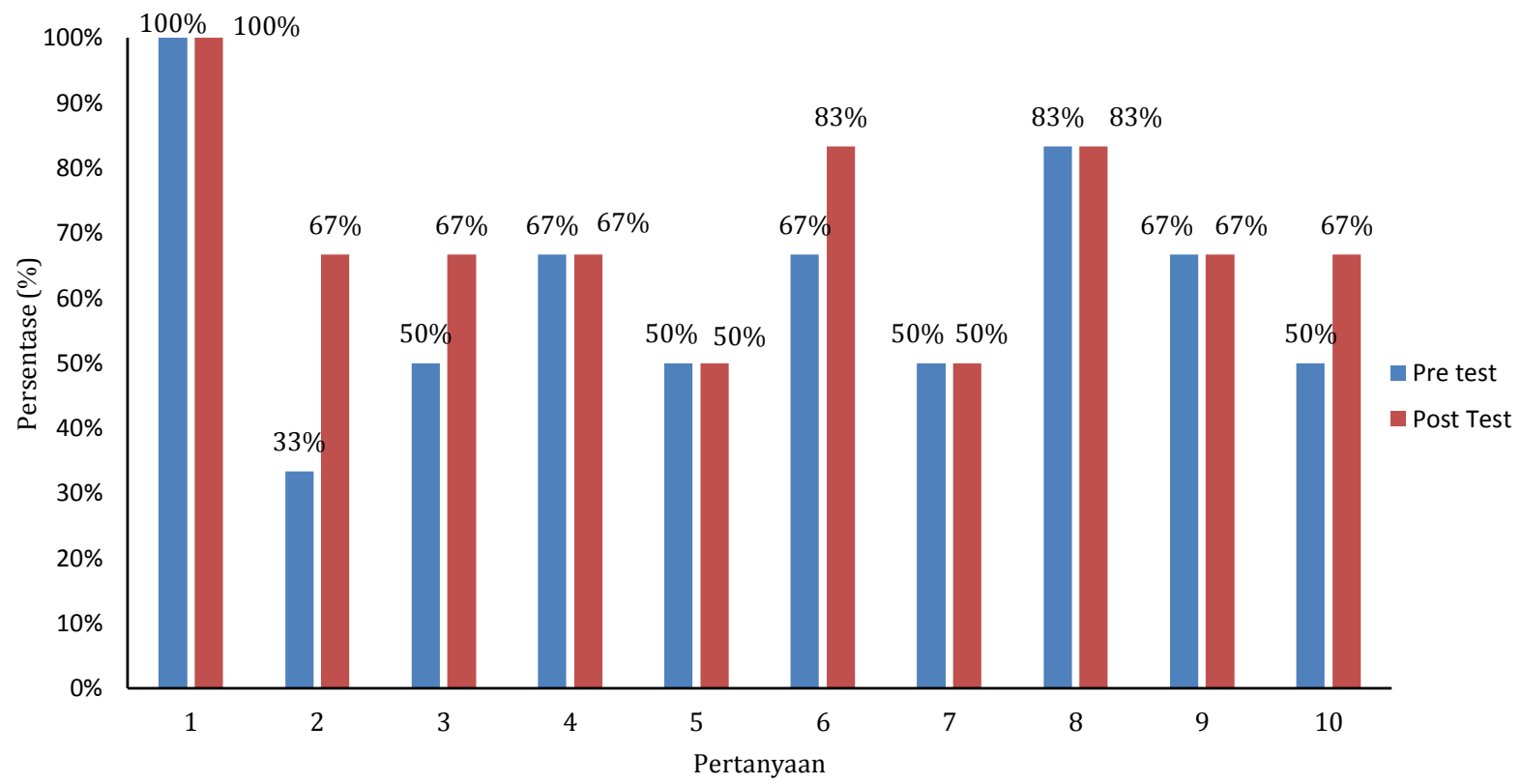

Keterangan: 1 = pengertian awal koperasi; $2=$ persyaratan pendirian koperasi; $3=$ struktur organisasi koperasi; $4=$ tujuan koperasi; 5= prinsip koperasi; 6= hak dan kewajiban anggota; 7= kesediaan berkoperasi; 8= kendala koperasi; 9= persyaratan anggota koperasi; dan $10=$ manfaat pelatihan manajemen koperasi.

Gambar 5 Hasil evaluasi pelatihan perkoperasian. 
terkandung muatan menolong diri sendiri, kerja sama untuk kepentingan bersama (gotong royong), dan beberapa esensi moral lainnya. Koperasi Akesalaka Monge Bahari merupakan kelompok usaha dari masyarakat Desa Saramaake, yang mengembangkan beberapa produk ikan laut, antara lain ikan teri kering terkemas, teri krispi, dan sambal teri. Hal ini dilakukan untuk meningkatkan nilai tambah ikan melalui diversifikasi produk. Sebelumnya hanya ikan teri curah yang dihasilkan masyarakat dengan nilai berkisar Rp 20.000 (ukuran gross atau besar) sampai Rp 50.000 (ukuran kecil atau halus). Ketika dikembangkan menjadi produk olahan dalam bentuk teri krispi maka nilainya menjadi Rp $100.000 / \mathrm{kg}$, bahkan jika dalam bentuk sambal teri menjadi Rp 300.000/kg. Pada Koperasi KKSG, melalui koperasi dapat meningkatkan penghematan biaya transportasi dalam pengadaan/pembelian bahan baku kain sutera (benang dan pewarna) karena pengadaannya dilakukan melalui koperasi, padahal sebelumnya dilakukan secara perorangan (Sehabudinet al. 2017).

\section{SIMPULAN}

Berdasarkan kegiatan yang dilakukan, kelembagaan yang sudah dibangun sejak 2016 ditingkatkan statusnya dari kelompok nelayan dan pengolah ikan, menjadi KUB, kemudian dikembangkan menjadi koperasi pada tahun 2017. Proses pengembangan kelembagaan koperasi dari KUB menjadi koperasi dimulai dengan rapat persiapan pembentukan koperasi, proses pendaftaran melalui akta notaris, verifikasi kelengkapan persyaratan, sampai dengan terbitnya SK badan Hukum Koperasi, memerlukan tahapan yang cukup panjang. Koperasi yang dibentuk bernama koperasi produsen Akesalaka Monge Bahari dan telah mendapatkan badan hukum No.006389/BH/ M.KUKM.2/XI/2017. Keberadaan koperasi ini mampu menerapkan proses kebersamaan dalam pengelolaan produksi ikan yang lebih baik, serta pengembangan pasar yang lebih luas. Pelatihan dan pendampingan perkoperasian mampu meningkatkan pengetahuan dan pemahaman pengelola SDM koperasi tentang perkoperasian dan manajemen/tata kelola koperasi. Melalui pengembangan kelembagaan ini, para nelayan dan pengolah hasil laut dapat lebih mampu mengelola usahanya secara mandiri serta mampu meningkatkan bargaining position dalam pemasaran ikan teri dan produk olahan hasil laut lainnya.

Kementerian Koperasi dan UKM perlu menyususun regulasi dalam rangka pendirian dan pengembangan koperasi, agar prosedur dan persyaratan pendirian koperasi lebih sederhana, lebih cepat, dan lebih murah, bahkan jika dimungkinkan biaya pendirian koperasi khususnya biaya akte notaris disubsidi/ditanggung pemerintah. Proses pendirian koperasi memerlukan sosialisasi yang intensif kepada masyarakat oleh Dinas Koperasi Kabupaten terutama untuk memberikan pemahaman pentingnya berkoperasi. Pelatihan dan pendampingan yang kontinu perlu dilakukan untuk menjamin keberlanjutan program pengembangan koperasi, khususnya dalam rangka peningkatan pengetahuan dan keterampilan SDM pengelola koperasi.

\section{UCAPAN TERIMA KASIH}

Kami mengucapkan terima kasih atas segala bantuan Taufik M Yusuf, SPi dan Irma, SPi, MSi selaku pendamping lapang yang telah membantu dalam kegiatan ini. Ucapan terima kasih disampaikan kepada PT Antam, Tbk atas fasilitasi pembiayaan dan bantuan lainnya dalam rangka pelaksanaan program pemberdayaan masyarakat nelayan Desa Saramaake Kabupaten Halmahera Timur. Juga kepada Dinas Koperasi, UMKM, Perdagangan dan Perindustrian Kab Halmahera Timur, Notaris, dan Kementerian Koperasi dan UKM atas bantuannya dalam proses pembentukan Koperasi Akesalaka Monge Bahari sampai dengan diperolehnya badan hukum koperasi. Terima kasih juga kami sampaikan kepada para anggota Koperasi Akesalaka Monge Bahari atas segala bantuan dan kerja sama dalam pelaksanaan kegiatan ini.

\section{DAFTAR PUSTAKA}

Budi FS, Herawati D, Purnomo J, Sehabudin U, Sulistiono, Nugroho T. 2017. Peningkatan kualitas dan diversifikasi produk ikan teri untuk pemberdayaan masyarakat di Desa Saramaake, Halmahera Timur. Agrokreatif Jurnal Ilmiah Pengabdian kepada Masyarakat. 3(2): 89-99. https://doi.org/10.29244/ agrokreatif.3.2.89-99

Budi FS, Purnomo J, Sulistiono, Darmanto, Arisyono. 2018. Pengembangan produk ikan 
teri dan sertifikasinya dalam rangka pemberdayaan masyarakat di Desa Saramaake, Halmahera Timur. Agrokreatif Jurnal Ilmiah Pengabdian kepada Masyarakat. 4(2): 143-155. https://doi.org/10.29244/ agrokreatif.4.2.143-155

Darmansah A, Sulistiono, Nugroho T, Supriyono E. 2016a. Pemberdayaan masyarakat melalui pengembangan polikultur bandeng dan udang di Desa Karangsong, Indramayu, Jawa Barat. Agrokreatif Jurnal Ilmiah Pengabdian kepada Masyarakat. 2(2): 92-99

Darmansah A, Sulistiono, Nugroho T, Supriyono E. 2016b. Pemberdayaan masyarakat melalui pengembangan budi daya ikan lele di Desa Balongan, Indramayu, Jawa Barat. Agrokreatif Jurnal Ilmiah Pengabdian kepada Masyarakat. 2(1): 8-16. https://doi.org/10.29244/ agrokreatif.2.1.8-16

Desa Saramaake. 2017. Monografi Desa Saramaake, Kecamatan Wasile Selatan, Kabupaten Halmahera Timur.

Insani MTS, Kadir I, Utomo NBP, Afandi R, Sulistiono, Nugroho T, Murhum M, Manan H. 2017. Pengembangan budi daya ikan kerapu bebek (Chromileptes altivelis) di Pulau Gebe, Halmahera Tengah, Maluku Utara. Agrokreatif Jurnal Ilmiah Pengabdian kepada Masyarakat. 3(1): 24-33. https://doi.org/10.29244/ agrokreatif.3.1.24-33

Ma'arif R, Zulkarnain, Nugroho T, Sulistiono. 2016. Pemberdayaan masyarakat nelayan melalui pengembangan perikanan tangkap di Desa Majakerta, Indramayu, Jawa Barat. Agrokreatif Jurnal Ilmiah Pengabdian kepada Masyarakat. 2(1): 17-24. https://doi.org/10. 29244/agrokreatif.2.1.17-24

Nasdian FT. 2014. Pengembangan masayarakat. Jakarta (ID): Yayasan Obor Indonesia.

Nugroho M. 2015. Pemberdayaan masyarakat nelayan miskin melalui usaha pengolahan ikan tradisional: kajian pengembangan diversifikasi pengolahan ikan secara tradisional di Kecamatan Lekok, Kabupaten Pasuruan. Neptunus. 19(1):14-22

Sehabudin U, Budi FS, Herawati D, Purnomo J, Sulistiono. 2017. Inisiasi pengembangan pemasaran ikan teri (stolephorus spp) dan pembentukan kelembagaan dalam rangka pemberdayaan masyarakat di Desa Saramaake Halmahera Timur. Agrokreatif
Jurnal Ilmiah Pengabdian kepada Masyarakat. 3(1): 60-70. https://doi.org/10.29244/ agrokreatif.3.1.60-70

Sehabudin U, Solihin DD, Yani A, Bakhtiar R. 2017. Evaluasi program pengembangan agribisnis sutera di Desa Panawuan Kecamatan Tarogong Kidul dan Desa Wangunjaya Kecamatan Banjarwangi Kabupaten GarutJawa Barat. LPPM IPB-PT PGN, Tbk.

Sehabudin U, Solihin DD, Yani A, Bakhtiar R. 2016. Program pengembangan agribisnis sutera di Desa Panawuan, Kecamatan Tarogong Kidul dan Desa Wangunjaya Kecamatan Banjarwangi Kabupaten Garut-Jawa Barat. LPPM IPB-PT PGN, Tbk.

Sipahelut K. 2010. Analisis pemberdayaan masyarakat nelayan di Kecamatan Tobelo, Kabupaten Halmahera Timur. [Tesis]. Bogor (ID): Institut Pertanian Bogor. 112 hal.

Sulistiono, Priyanto R, Saharudin, Adiwirman, Syah D, Setiono DJ, Zulkarnaen. 2012. Pengembangan perikanan, pertanian, peternakan, pengolahan pangan, kelembagaan dan pemasaran di Pulau Gebe. Laporan Akhir. Kerjasama Pemerintah Daerah Halmahera Tengah, PT Aneka Tambang, dan Institut Pertanian Bogor. 192 hal.

Sulistiono, Priyanto R, Sunarminato T, Sumarti T, Syah D, Priyambodo S, Zulkarnaen, Herawati D. 2015. Program pemberdayaan ekonomi masyarakat Kecamatan Pulau Gebe. Laporan Akhir 2011-2015. Kerjasama Pemerintah Daerah Halmahera Tengah, PT Aneka Tambang Tbk, Institut Pertanian Bogor, dan Universitas Khairun. 301 hal.

Sulistiono, Budi FS, Herawati D, Purnomo J, Sehabudin U, Nugroho T. 2017. Pengelolaan pemberdayaan masyarakat pantai (melalui upaya peningkatan kualitas hasil tangkap dan inisiasi pengembangan pemasaran ikan teri (Stolephorus spp) di Saramaake, Halmahera Timur, Maluku Utara): pemetaan kebutuhan, program dan evaluasi. Paper. 24 hal.

Sulistiono, Setiabudi F, Herawati D, Purnomo J, Sehabudin U, Nugroho T, Handayani R, Sudaramanto, Arisyono. 2018. Coastal community empowerment management of anchovy (Stolephorus spp) fishery in Saramaake, North Moluccas Province, Indonesia: need assessment, program and evaluation. Journal of Community Development 
Research (Humanities and Social Sciences). 11(3): 39-55.

Sulistiono, Zulkarnaen, Nugroho T. 2018. Edukasi pelestarian sumberdaya dan lingkungan pantai pada nelayan perikanan bagan Desa Saramaake, Halmahera Timur, Indonesia. Jurnal Pendidikan dan Pemberdayaan Masyarakat. 5(2): 183-194.

Utomo NBP, Sulistiono, R Affandi, T Nugroho, M Murhum, H Manan. 2018. Penampungan Lobster (Panulirus spp.) dalam Rangka Pemberdayaan Masyarakat di Pulau Gebe,
Halmahera Tengah, Maluku Utara. Agrokreatif Jurnal Ilmiah Pengabdian kepada Masyarakat. 2(1): 81-91. https://doi.org/10.29244/ agrokreatif.4.2.81-91

Yanti D, Permata DA. 2016. Pemberdayaan masyarakat melalui produk olahan di Nagari Tarung Tarung, Kecamatan Rao, Kabupaten Pesaman, Sumatera Barat. Agrokreatif Jurnal Ilmiah Pengabdian kepada Masyarakat. 2(2): 73-80. https://doi.org/10.29244/agrokreatif. 2.2.73-80 